\title{
GAMBARAN KADAR KOLESTEROL PADA WANITA LANSIA YANG MENGKONSUMSI TEH HITAM DI PANTI JOMPO AISYIYAH KELURAHAN SUMBER
}

\author{
Prisilia Kurnia Wati ${ }^{1, *}$, Hari Saktiningsih ${ }^{2}$ \\ ${ }^{1,2}$ Sekolah Tinggi Ilmu Kesehatan Nasional Surakarta Surakarta, 57552, Indonesia \\ ${ }^{1}$ priciliakurnia28@gmail.com*
}

\begin{abstract}
Abstrak
Latar Belakang : Teh adalah minuman yang paling banyak dikonsumsi oleh manusia, dan sudah menjadi kebiasaan. Teh hitam adalah jenis teh yang sering muncul dan diminum karena memiliki warna, rasa, dan aroma yang unik. Teh hitam mengandung senyawa bioaktif (polifenol) bernama flavonoid dalam bentuk theaflavin, thearubigin, dan katekin yang dapat mengurangi kolesterol darah dengan menghambat penyerapan kolesterol di usus.

Tujuan : Penelitian ini bertujuan untuk mengetahui gambaran kadar kolesterol pada wanita lanjut usia yang mengkonsumsi teh hitam di Panti Jompo Aisyiyah. Kelurahan Sumber.

Metode: Penelitian ini menggunakan penelitian deskriptif dengan pendekatan cross sectional, dengan 15 subjek di Panti Jompo Aisyiyah Kelurahan Sumber dengan teknik total sampling. Penelitian dilakukan dengan memberikan informed consent dan kuesioner, dan kadar kolesterol diperiksa dengan metode CHOD-PAP dengan fotometer Clima MC 15. Data yang diperoleh disajikan dalam bentuk tabel deskriptif dan tabulasi silang, kemudian dihitung frekuensi, rerata, persentase dan standar deviasi.

Hasil : Penelitian terhadap 15 responden menunjukkan bahwa semua responden memiliki kadar kolesterol dalam batas normal.

Simpulan: Tingkat kolesterol pada wanita lanjut usia yang mengonsumsi teh hitam memiliki kadar kolesterol dalam batas normal.

Kata kunci: Kolesterol; Lansia; Teh Hitam

\section{AN OVERVIEW OF CHOLESTEROL LEVELS IN ELDERLY WOMAN WHO CONSUME BLACK TEA AT PANTI JOMPO AISYIYAH KELURAHAN SUMBER}

\begin{abstract}
Background: Tea is the most consumed beverage by humans, and it has become a habit. Black tea is a type of tea that is often appeared and drunk because it has a unique color, taste and aroma. Black tea contains bioactive compounds (polyphenols) named flavonoids in the form of theaflavin, thearubigin, and catechins which can reduce blood cholesterol by inhibiting the absorption of cholesterol in the intestine.

The purpose: of this study was to determine the description of cholesterol levels in elderly woman who consume black tea at Panti Jompo Aisyiyah Kelurahan Sumber.
\end{abstract}


Methode: This research used descriptive research with cross sectional approach, with 15 subjects in Panti Jompo Aisyiyah Kelurahan Sumber by total sampling technique. The study was conducted by giving informed consent and questionnaires, and the cholesterol levels were examined by the CHOD-PAP method with a Clima MC 15 photometer. The data obtained were presented in the form of descriptive tables and cross tabulation, then calculated frequencies, mean, percentage and standard deviation.

Result: The results of the study of 15 respondents showed that all respondents had cholesterol levels within normal limits.

Conclusion: Cholesterol levels in elderly women who consume black tea have cholesterol levels within normal limits.

Keywords: Cholesterol; Elderly; Black Tea

\section{PENDAHULUAN}

Kebiasaan minum teh sudah menjadi budaya bagi penduduk di dunia. Teh merupakan minuman yang paling banyak dikonsumsi oleh manusia, selain air putih. Teh memiliki warna, rasa dan aroma yang khas. Teh hitam merupakan jenis teh yang sering beredar dan sering diminum, termasuk di Indonesia. Tingkat perkembangan ketersediaan konsumsi teh di Indonesia tertinggi dicapai pada tahun 2016 sebesar 114.793 ton dimana konsumsinya naik sebesar 33,69\% terhadap tahun sebelumnya (Zikria, 2017).

Mayoritas masyarakat Indonesia mengkonsumsi teh tanpa mengetahui manfaat dari teh itu sendiri. Teh hitam mengandung senyawa zat bioaktif (polifenol) yang terdapat di dalam daun teh. Secara umum, polifenol terbagi menjadi dua bagian besar yaitu flavonoid dan asam fenolat (Sudaryat, 2015). Theaflavin merupakan antioksidan yang terkandung di dalam teh hitam. Antioksidan merupakan senyawa pemberi elektron, yang mampu menginaktivasi berkembangnya reaksi oksidan, dengan cara mencegah terbentuknya radikal bebas. Theaflavin menunjukkan efektivitasnya dalam mencegah terjadinya oksidasi lipid atau memotong proses berantai oksidasi lipid daripada epigalocathecin gallat (EGCG) (Anggraini, 2017).

Kolesterol merupakan zat lemak yang beredar di dalam darah, berwarna kekuningan dan berupa seperti lilin, yang diproduksi oleh hati. Kolesterol termasuk golongan lipid yang tidak terhidrolisis dan merupakan sterol utama dalam jaringan tubuh manusia. Kolesterol merupakan bahan pembentukan sejumlah steroid seperti asam empedu, asam folat, hormon adrenal korteks, esterogen dan progesteron (Almatsier, 2009).

Lanjut usia (lansia) merupakan tahap akhir dari perkembangan hidup manusia. Proses bertambahnya usia akan berdampak pada berbagai aspek kehidupan, baik sosial, ekonomi, maupun kesehatan. Dari segi kesehatan, dengan semakin bertambahnya usia maka fungsi biologis akan mengalami proses penuaan secara terus-menerus yang ditandai menurunnya daya tahan fisik sehingga rentan terhadap serangan penyakit yang dapat menyebabkan kematian. Kematian terbanyak akibat penyakit tidak menular antara lain penyakit kardiovaskuler dan hiperkolesterolemia (Suwarsi, 2017). 
Berdasarkan uraian diatas peneliti ingin mengetahui "Gambaran Kadar Kolesterol Pada Wanita Lansia Yang Mengkonsumsi Teh Hitam di Panti Jompo Aisyiyah Kelurahan Sumber".

\section{METODE}

Penelitian ini dilakukan pada bulan Februari sampai Juni 2019. Tempat pengambilan sampel di Panti Jompo Aisyiyah Kelurahan Sumber. Tempat pemeriksaan kadar kolesterol dilakukan di Laboratorium Kimia Klinik STIKES Nasional Surakarta. Alat yang digunakan antara lain informed consent, kuesioner, Fotometer RAL Clima MC-15, tourniquet, spuit, jarum, vacum tube, kapas, tissue, micropipet $10 \mu \mathrm{l}$ dan $100 \mu \mathrm{l}$, blue tip, yellow tip, ice box, thermometer, dan cup sampel. Bahan yang digunakan antara lain alkohol 70\%, reagen cholesterol, aquabidest, dan sampel serum. Cara Kerja : Penelitian diawali dengan memberikan penjelasan mengenai prosedur penelitian yang disertai dengan pemberian informed consent dan kuesioner, serta menjelaskan kepada responden bahwa responden yang bersedia akan diminta untuk berpuasa sebelum dilakukan pengambilan darah.

Responden yang diambil dalam penelitian ini adalah lansia yang memiliki kebiasaan konsumsi teh hitam setiap hari dan bersedia menandatangani informed consent. Penelitian ini menggunakan teknik Total Sampling. Setelah dilakukan pengambilan darah vena, kemudian dilakukan pemeriksaan dengan metode CHOD-PAP menggunakan Fotometer RAL Clima MC-15 dengan panjang gelombang $546 \mathrm{~nm}$, program $\mathrm{C} / \mathrm{F}$, kemudian diinkubasi pada suhu $20-25^{\circ} \mathrm{C}$ atau suhu $37^{\circ} \mathrm{C}$ selama 10 menit.

\section{HASIL DAN PEMBAHASAN}

Berdasarkan pada penelitian ini peneliti berhasil mendapatkan data hasil pemeriksaan kadar kolesterol pada wanita lansia di Panti Jompo Aisyiyah Kelurahan Sumber yang disajikan dalam tabel 1 sebagai berikut.

Tabel 1. Hasil Pemeriksaan Kadar Kolesterol Pada Wanita Lansia Di Panti Jompo Aisyiyah Kelurahan Sumber.

\begin{tabular}{|c|c|c|c|c|c|}
\hline No & $\begin{array}{c}\text { Kode } \\
\text { Sampel }\end{array}$ & $\begin{array}{c}\text { Jenis } \\
\text { Kelamin }\end{array}$ & $\begin{array}{c}\text { Usia } \\
\text { (Tahun) }\end{array}$ & $\begin{array}{c}\text { Kadar Kolesterol } \\
(\mathbf{m g} / \mathrm{dl})\end{array}$ & Keterangan \\
\hline 1 & $\mathrm{AC} 1$ & $\mathrm{P}$ & 62 & 80 & Normal \\
\hline 2 & $\mathrm{AC} 2$ & $\mathrm{P}$ & 73 & 105 & Normal \\
\hline 3 & $\mathrm{AC} 3$ & $\mathrm{P}$ & 68 & 84 & Normal \\
\hline 4 & $\mathrm{AC} 4$ & $\mathrm{P}$ & 69 & 72 & Normal \\
\hline 5 & AC 5 & $\mathrm{P}$ & 64 & 80 & Normal \\
\hline 6 & AC 6 & $\mathrm{P}$ & 60 & 72 & Normal \\
\hline 7 & $\mathrm{AC} 7$ & $\mathrm{P}$ & 83 & 64 & Normal \\
\hline 8 & AC 8 & $\mathrm{P}$ & 71 & 88 & Normal \\
\hline 9 & AC 9 & $\mathrm{P}$ & 79 & 56 & Normal \\
\hline 10 & $\mathrm{AC} 10$ & $\mathrm{P}$ & 84 & 86 & Normal \\
\hline 11 & $\mathrm{AC} 11$ & $\mathrm{P}$ & 61 & 70 & Normal \\
\hline 12 & AC 13 & $\mathrm{P}$ & 71 & 79 & Normal \\
\hline 13 & $\mathrm{AC} 14$ & $\mathrm{P}$ & 74 & 57 & Normal \\
\hline 14 & $\mathrm{AC} 15$ & $\mathrm{P}$ & 80 & 101 & Normal \\
\hline
\end{tabular}




\begin{tabular}{cccccc}
\hline 15 & AC 16 & P & 77 & 64 & Normal \\
\hline Sumber : Data Primer Bulan April 2019 & & &
\end{tabular}

Tabel 1 diatas menggambarkan hasil pemeriksaan kadar kolesterol pada wanita lansia di Panti Jompo Aisyiyah Kelurahan Sumber dimana seluruh responden memiliki kadar kolesterol dalam batas normal.

Tabel 2. Distribusi Frekuensi Relative Karakteristik Responden

\begin{tabular}{ccccc}
\hline No. & Kelompok & & Frekuensi & Presentase (\%) \\
\hline 1. & Jumlah Konsumsi teh & $\leq 5$ gelas/hari & 13 & 86,7 \\
& & $>5$ gelas/hari & 2 & 13,3 \\
2. & \multirow{2}{*}{ Konsumsi Obat } & Ya & 2 & 13,3 \\
& & Tidak & 13 & 86,7 \\
3. & \multirow{2}{*}{ Status Hipertensi } & Normotensi & 9 & 60 \\
& & Hipertensi & 6 & 40 \\
\hline
\end{tabular}

Sumber : Data Primer dan Data Sekunder Bulan April 2019

Tabel 2 didapatkan sebanyak 13 responden (86,7\%) yang mengkonsumsi teh hitam $\leq 5$ gelas/hari. Responden yang mengkonsumsi obat penurun kolesterol sebanyak 2 orang $(13,3 \%)$. Responden yang memiliki status hipertensi sebanyak 6 orang $(40 \%)$.

Tabel 3. Data Deskriptif Kadar Kolesterol Pada Wanita Lansia Yang Konsumsi Teh Hitam di Panti Jompo Aisyiyah Sumber

\begin{tabular}{cccccccc}
\hline No & Kelompok & N & Mean & Min & Max & Std.Dev & Std.Error \\
\hline 1 & Kadar Kolesterol & 15 & 77,2 & 56 & 105 & 14,4 & 3,7 \\
\hline Sumber : Data Primer Buln & &
\end{tabular}

Sumber : Data Primer Bulan April 2019

Tabel 3 didapatkan nilai kadar kolesterol pada wanita lansia yang mengkonsumsi teh hitam setiap hari di Panti Jompo Aisyiyah Sumber yaitu dengan rata-rata 77,2 $\mathrm{mg} / \mathrm{dl}$, nilai minimal $56 \mathrm{mg} / \mathrm{dl}$, nilai maksimal $105 \mathrm{mg} / \mathrm{dl}$, dan standar deviasi 14,4 .

Tabel 4. Data Deskriptif Kadar Kolesterol Pada Wanita Lansia Yang Konsumsi Teh Hitam di Panti Jompo Aisyiyah Sumber berdasarkan Jumlah Konsumsinya

\begin{tabular}{cccccccc}
\hline No & Jumlah Konsumsi Teh & N & Mean & Min & Max & Std.Dev & Std.Error \\
\hline 1. & $\leq 5$ gelas/hari & 13 & 78 & 56 & 105 & 0,4 & 0,1 \\
2. & $>$ 5 gelas/hari & 2 & 72 & 72 & 72 & 0,4 & 0,1 \\
\hline
\end{tabular}

Sumber : Data Primer Bulan April 2019

Tabel 4. menggambarkan pada konsumsi $\leq 5$ gelas/hari terdapat 13 responden dengan rata-rata $78 \mathrm{mg} / \mathrm{dl}$, serta didapatkan nilai minimal 56 dan nilai maksimal 105. Sedangkan konsumsi $>5$ gelas/hari terdapat 2 responden dengan rata-rata 72 $\mathrm{mg} / \mathrm{dl}$, serta nilai minimal 72 dan nilai maksimal 72. Pada tabel ini didapatkan nilai standar deviasi sebesar 0,4 dan standar error 0,1 . 
Tabel 5. Tabulasi Silang Hasil Kadar Kolesterol dengan Jumlah Konsumsi Teh Hitam

\begin{tabular}{|c|c|c|c|c|}
\hline \multirow[b]{2}{*}{ No } & \multirow[b]{2}{*}{ Jumlah Konsumsi Teh } & \multicolumn{2}{|c|}{ Kadar Kolesterol } & \multirow[b]{2}{*}{ Jumlah } \\
\hline & & Normal & Lebih dari normal & \\
\hline \multirow[t]{2}{*}{1.} & $\leq 5$ gelas/hari & 13 & 0 & 13 \\
\hline & Proporsi & $100 \%$ & $0 \%$ & \\
\hline \multirow[t]{3}{*}{2.} & $>5$ gelas/hari & 2 & 0 & 2 \\
\hline & Proporsi & $100 \%$ & $0 \%$ & \\
\hline & Jumlah & 15 & 0 & 15 \\
\hline
\end{tabular}

Sumber : Data Primer Bulan April 2019

Tabel 5. menggambarkan sebanyak 13 responden (100\%) pada konsumsi teh hitam $\leq 5$ gelas/hari memiliki kadar kolesterol dalam batas normal dan sebanyak 2 responden $(100 \%)$ dengan konsumsi teh hitam $>5$ gelas/hari juga memiliki kadar kolesterol dalam batas normal.

Tabel 6. Data Deskriptif Kadar Kolesterol Pada Wanita Lansia Yang Konsumsi Teh Hitam di Panti Jompo Aisyiyah Sumber berdasarkan konsumsi obat

\begin{tabular}{cccccccc}
\hline No & Konsumsi Obat & N & Mean & Min & Max & Std.Dev & Std.Error \\
\hline 1. & Ya & 2 & 84,00 & 80 & 88 & 5,6 & 4,0 \\
2. & Tidak & 13 & 76,15 & 56 & 105 & 15,1 & 4,2 \\
\hline
\end{tabular}

Sumber : Data Primer Bulan April 2019

Tabel 6. menggambarkan terdapat 2 responden yang mengkonsumsi obat penurun kolesterol dengan rata-rata 84,00, serta didapatkankan nilai minimal 80 dan nilai maksimal 88 dengan standar deviasi 5,6 dan standar error 4,0. Sedangkan sebanyak 13 responden yang tidak mengkonsumsi obat memiliki rata-rata sebesar 76,15, dan didapatakan nilai minimalnya 56 dan nilai maksimal 105 dengan standar deviasi 15,1 dan standar error 4,2.

Tabel 7. Tabulasi Silang Hasil Kadar Kolesterol dengan Konsumsi Obat

\begin{tabular}{ccccc}
\hline & & \multicolumn{2}{c}{ Kadar Kolesterol } & \multirow{2}{*}{ No } \\
\cline { 3 - 4 } Nonsumsi Obat & Normal & Lebih dari normal & Jumlah \\
\hline 1. & Ya & 2 & 0 & 2 \\
& Proporsi & $100 \%$ & $0 \%$ & 13 \\
2. & Tidak & 13 & 0 & 13 \\
\hline & Proporsi & $100 \%$ & $0 \%$ & 15 \\
\hline & Jumlah & 15 & 0 &
\end{tabular}

Sumber : Data Primer Bulan April 2019

Tabel 7. menggambarkan terdapat 2 responden (100\%) yang mengkonsumsi obat penurun kolesterol memiliki kadar kolesterol dalam batas normal dan terdapat 13 responden $(100 \%)$ yang tidak mengkonsumsi obat penurun kolesterol memiliki kadar kolesterol dalam batas normal. 
Tabel 8. Tabulasi Silang Hasil Kadar Kolesterol dengan Status Hipertensi

\begin{tabular}{ccccc}
\hline & & \multicolumn{2}{c}{ Kadar Kolesterol } & \\
\cline { 3 - 4 } No & Status Hipertensi & Normal & Lebih dari normal & Jumlah \\
\hline 1. & Ya & 6 & 0 & 6 \\
& Proporsi & $100 \%$ & $0 \%$ & 9 \\
2. & Tidak & 9 & 0 & \\
& Proporsi & $100 \%$ & $0 \%$ & 15 \\
\hline
\end{tabular}

Sumber : Data Primer Bulan April 2019

Tabel 8. menggambarkan terdapat 6 responden (100\%) yang memiliki status hipertensi memiliki kadar kolesterol dalam batas normal dan terdapat 9 responden $(100 \%)$ yang tidak memiliki status hipertensi memiliki kadar kolesterol dalam batas normal.

Penelitian ini menggambarkan kadar kolesterol pada wanita lansia yang mengkonsumsi teh hitam di Panti Jompo Aisyiyah Kelurahan Sumber. Dari hasil yang didapatkan, dilihat pada tabel 1 seluruh responden memiliki kadar kolesterol normal. Rata-rata kadar kolesterol responden yang disajikan dalam tabel 2 adalah 77,2 mg/dl, dengan kadar kolesterol terendah 56 mg/dl, dan kadar tertinggi 105 $\mathrm{mg} / \mathrm{dl}$.

Tabel 3 menunjukkan kadar kolesterol pada konsumsi teh hitam konsumsi $\leq 5$ gelas/hari sebanyak 13 responden memiliki rata-rata $78 \mathrm{mg} / \mathrm{dl}$, sedangkan konsumsi > 5 gelas/hari sebanyak 2 responden memiliki rata-rata $72 \mathrm{mg} / \mathrm{dl}$. Penurunan dari kolesterol tersebut berasal dari senyawa flavonoid yang terkandung di dalam teh hitam yang mampu menghambat formasi misel sehingga absorbsi kolesterol di usus juga terhambat. Sedangkan pada penelitian yang dilakukan Troup et al (2015) dengan pemberian 5 gelas teh hitam setiap hari pada responden hiperkolesterolemia tidak didapatkan hasil yang signifikan terhadap perubahan kadar kolesterolnya.

Keterbatasan dalam penelitian ini peneliti tidak dapat menyimpulkan bahwa konsumsi teh hitam setiap hari mampu menurunkan kadar kolesterol, dikarenakan hanya menggambarkan kadar kolesterol satu kali pengukuran saja.

Tabel 5 menunjukkan terdapat 2 responden $(13,3 \%)$ yang mengkonsumsi obat penurun kolesterol yaitu simvastatin dengan dosis $10 \mathrm{mg}$. Setelah dilakukan wawancara ulang pada kedua responden, responden mengurangi bahkan menghindari makanan yang mengandung lemak jenuh seperti jeroan dan kuning telur. Sesuai dengan penelitian Dewi (2014) bahwa konsumsi obat simvastatin dapat menurunkan kadar kolesterol darah. Simvastatin bekerja didalam tubuh dengan cara menghambat 3-hidroxy-3 methylglutaryl koenzi A (HMG-CoA) reduktase.

Pada tabel 7 menunjukkan jumlah responden yang memiliki status hipertensi terdapat sebanyak 6 responden $(40 \%)$. Data dari status hipertensi tersebut berasal dari data sekunder berupa Rekam Medik responden yang didapatkan dari Pengurus Panti Jompo Aisyiyah Kelurahan Sumber. Responden yang memiliki status hipertensi tersebut memiliki kadar kolesterol dalam batas normal. Secara teori, tekanan darah dapat dipengaruhi oleh banyak faktor seperti kurangnya 
aktivitas fisik, konsumsi makanan yang banyak mengandung garam dan lemak, usia, serta faktor genetik. Dalam penelitian Angesti (2018) menunjukkan bahwa riwayat hipertensi keluarga menjadi faktor dominan terhadap terjadinya hipertensi.

Dalam penelitian ini peneliti tidak mengendalikan faktor genetik, aktivitas fisik, dan asupan makanan. Faktor yang dikendalikan antara lain jumlah konsumsi teh, konsumsi obat dan status hipertensi. Faktor genetik tidak dapat dikendalikan karena diturunkan dari keluarganya. Keluarga yang memiliki kadar kolesterol tinggi, kemungkinan keturunannya memiliki kadar LDL kolesterol tinggi bisa terjadi (Graha, 2010).

Aktivitas fisik tidak dikendalikan karena setiap responden memiliki kegiatan yang berbeda-beda. Kegiatan yang dilakukan antara lain senam, berkebun, bersepeda, berjalan, dan memotong sayuran. Makanan yang disediakan oleh Panti lengkap dengan sayur, lauk, dan buah. Tetapi tidak semua lansia mau mengkonsumsi makanan yang sudah disiapkan. Selain itu, adanya pedagang yang masuk ke wilayah Panti, membuat lansia menjadi membeli makanan dari luar. Hal ini menyebabkan asupan makanan yang dikonsumsi setiap lansia tidak sama, sehingga peneliti tidak dapat mengendalikan asupan makanan.

Makanan yang masuk ke dalam tubuh sebagian besar terdiri dari trigliserida yang dihidrolisis menjadi asam lemak. Asam lemak tersebut akan mengalami oksidasi menjadi asetil-KoA untuk menghasilkan energi. Bila asupan makanan berlemak berlebihan pembentukan asetil Ko-A di hati juga akan meningkat sehingga produksi kolesterol akan meningkat. Keterkaitan kadar kolesterol darah dengan konsumsi lemak sebagai sumber energi menunjukkan peningkatan, sebab lemak memberikan nilai tambah terhadap kadar kolesterol. Semakin tinggi lemak yang dikonsumsi tetapi apabila penggunaan energi yang tidak seimbang akan menyebabkan meningkatnya kadar kolesterol darah (Yuliantini, 2015).

Selain faktor di atas peneliti telah berusaha untuk mengendalikan faktor teknis dari mulai tahap pra analitik, analitik dan post analitik. Pada tahap pra analitik, peneliti satu hari sebelum dilakukan pengambilan darah memberitahukan dan mengingatkan responden untuk berpuasa selama 8-10 jam karena pemeriksaan yang dilakukan adalah kolesterol darah yang diharuskan untuk berpuasa supaya tidak mempengaruhi hasil pemeriksaan. Peneliti juga meminta bantuan dari pihak pengurus Panti untuk mengingatkan lansia yang menjadi responden untuk berpuasa. Pengambilan sampel dilakukan dengan menggunakan vacum tube dengan tutup berwarna merah. Pendistribusian sampel dari Panti Jompo Aisyiyah Kelurahan Sumber menuju Laboratorium Kimia Klinik STIKES Nasional menggunakan ice box berisi dry ice beku. Untuk pengendalian suhu dilakukan menggunakan thermometer suhu yaitu pada suhu $2-8^{\circ} \mathrm{C}$. Waktu yang diperlukan untuk pendistribusian sampel darah selama 20 menit dan pemusingan serta pemisahan serum dari darah dilakukan sebelum 2 jam.

Pada tahap analitik dilakukan pemipetan sampel serum dan reagen menggunakan mikropipet, dengan bantuan yellow tip dan blue tip. Reagen sebelumnya sudah dikeluarkan dari almari es untuk menyesuaikan suhu agar stabil dengan suhu ruangan. Kemudian dilakukan pemeriksaan kadar kolesterol dengan 
metode enzimatic colorimetric CHOD-PAP menggunakan alat Fotometer RAL Crima Mc-15.

Pada tahap post analitik hasil pemeriksaan kadar kolesterol diinterpretasikan dengan nilai normal. Pelaporan hasil pemeriksaan melalui pelampiran print out dari fotometer kemudian divalidasi oleh instruktur laboratorium.

\section{SIMPULAN}

Kadar kolesterol pada wanita lansia yang mengkonsumsi teh hitam memiliki kadar kolesterol dalam batas normal baik berdasarkan jumlah konsumsi teh hitam per hari, konsumsi obat maupun status hipertensinya.

\section{SARAN}

Bagi masyarakat, diharapkan masyarakat dapat memilih makanan yang sehat dan menghindari makanan yang berlemak jenuh, dan diimbangi dengan olahraga secara rutin, serta melakukan pemeriksaan rutin setiap bulan, seperti pemeriksaan kolesterol. Menjadikan penelitian-penelitian yang sudah dilakukan sebagai sumber bacaan, sehingga dapat mempermudah peneliti selanjutnya untuk menyusun Karya Tulis Ilmiah. Menjaga kesehatan seluruh lansia melalui pemeriksaan kolesterol dan tekanan darah secara rutin, serta menjaga pola makan lansia degan memperhatikan asupan makanan lansia dari luar Panti. Bagi peneliti selanjutnya diharapkan dapat melakukan penelitian sejenis dengan usia dan jenis kelamin yang bervariatif sehingga dapat digunakan sebagai pembanding seberapa besar kemungkinan terjadinya hiper-kolesterolemia. Penelitian juga dapat dilakukan dengan dua kali pengukuran kadar kolesterol sebelum dan sesudah mengkonsumsi teh hitam.

\section{DAFTAR PUSTAKA}

Almatsier, S. (2009). Prinsip Dasar Ilmu Gizi. Jakarta: Gramedia Pustaka Utama Anggraini, T. (2017). Proses dan Manfaat Teh. Padang: Penerbit Erka

Angesti, A., Triyanti., dan Ratu A.D.S. 2018. Riwayat Hipertensi Keluarga Sebagai Faktor Dominan Hipertensi Pada Remaja Kelas XI SMA Sejahtera 1 Depok Tahun 2017. Buletin Penelitian Kesehatan, Vol 46, No 1

Barret, K. E., Susan, M.B., Scort, B., dan Heddwen, L. (2017). Buku Ajar Fisiologi Kedokteran Ganong Edisi 24. Jakarta: EGC

Graha, K.C. (2010). Kolesterol. Jakarta: PT Elex Media Komputindo

Sudaryat, Y., Yayat Sudaryat., Mimin Kusmiyati., Citra Ratu Pelangi., Ardi Rustamsyah., dan Dadan Rohdiana. 2015. Aktivitas antioksidan seduhan sepuluh jenis mutu teh hitam (Camellia sinensis (L.) O. Kuntze) Indonesia. Jurnal Penelitian Teh dan Kina, Vol 18 No 2, 2015: 95- 100

Suwarsi, S. 2017. Penurunan Kadar Kolesterol Darah Pada KelompokLansia Yang Diberikan Terapi Aktivitas Fisik Di Desa Wedomartani Sleman. Jurnal Keperawatan Respati Yogyakarta, Vol 4 , No 3, 252-255 
Troup, R., Jennifer H., Susan K., Bharat T., Waseem K., David R., Nigel S., Bozena M., Daniel K., Alan J., and Myron G. 2015. Effect of Black Tea Intake on Blood Cholesterol Concentrations in Individuals with Mild Hypercholesterolemia: A Diet-Controlled Randomized Trial. Journal of the Academy of Nutrition And Dietetics. Vol 115, No 2

Yuliantini, E., Ayu P.S., dan Edy Nur. 2015. Hubungan Asupan Energi, Lemak Dan Serat Dengan Rasio Kadar KolesterolTotal-Hdl. Penelitian Gizi dan Makanan, Vol.38(2):139-147

Zikria, R. (2017). Teh. Jakarta: Pusat Data dan Sistem Informasi Pertanian 